\title{
Microbial Diversity in Skin and Soft Tissue Infection Bacteria Isolated from Two Different Geographical Regions in Egypt
}

\author{
Youssef E. A. Mawgoud ${ }^{1}$, Doaa M. Ghaith ${ }^{2}$, Mohamed E.A. Dawoud ${ }^{1}$ and Mohamed H. \\ Hussein $^{3}$
}

${ }^{I}$ Department of Botany and Microbiology, Faculty of Science, Cairo University, Cairo, Egypt. ${ }^{2}$ Department of Clinical and Chemical Pathology, Faculty of Medicine, Cairo University, Cairo, Egypt. ${ }^{3}$ NSA Diagnostic Laboratory, Microbiology Unit, Cairo, Egypt. Received: 19 August 2019/Accepted 20 Sept. 2019 / Publication date: 10 Oct. 2019

\begin{abstract}
This investigation aimed to study the variations of skin and soft tissue infections (SSTIs) bacteria from two different geographical and social areas. Along one year, 50 samples were collected from Sharm El-Sheikh and 50 from El-Sheikh Zaid .The number of bacterial infections in El- Sheikh Zaied 34 of 50 patients $(68 \%)$ that considered higher than in Sharm El- Sheikh City 21 of 50 patients $(48 \%)$. The infected females were more than males in both cities. Screening and identification of isolated pathogenic bacteria based on morphological, biochemical and molecular techniques. Molecular-based identification using 16S rDNA gene sequencing was conducted to emphasize the biochemical and genetical differences between isolates belonging to the same genus in both areas. There was a marked diversity in number and species of isolated bacteria. Out of 21 pathogenic bacteria isolated and identified from Sharm El- Sheikh, 7 were Staphylococcus aureus, 7 Klebseilla spp., 4 Pseudomonas spp. and 3 E. coli. Furthermore, the 34 pathogenic bacteria detected in El-sheikh Zaied included 10 Klebseilla spp. isolates, 9 Pseudomonas spp., 6 Acinetobacter spp., 3 Escherichia coli, 3 Proteus spp., 2 Staphylococcus aureus and one Morganella morganii.
\end{abstract}

Keywords: skin, soft tissue, bacteria, geographical regions

\section{Introduction}

Bacterial skin and soft tissue infections (SSTIs) are the common problem encountered in clinical practice, with approximately 14.2 million ambulatory care visits made for SSTIs in 2012( McCaig et al., 2012). Bacterial SSTIs range from superficial epidermal infections to life-threatening necrotizing fasciitis. Although most SSTIs can be managed on an outpatient basis, there is an alert remains for signs and symptoms indicative of a more serious infection requiring rapid evaluation and hospital admission. Patients with diminished immunity are highly susceptible and at increased risk of developing a SSTIs (Heinzelmann et al., 2002). There are several factors including age, obesity, malnutrition, endocrine and metabolic disorders influencing development of SSTIs. Most of bacterial SSTIs were caused by Gram-positive organisms, including Staphylococcus aureus; group A and B Streptococci, Streptococcus viridan; and Enterococcus faecalis. Also, Gram-negative organisms such as Haemophilus influenzae, Klebsiella pneumonia, Pseudomonas aeruginosa, Vibrio species, Mycobacterium species, Pseudomonas species, Aeromonas species and Proteus species (Church et al., 2006). The study will concern with patients from two different social and economic habits in addition to their variance in the geographical sites. Patient's samples of the study will be collected from a hospital in Sharm El-Sheikh city and another hospital in El-Sheikh Zaied city. Occurrence of travelers from different world countries in the coastal city for their different activities from diving to hot tub tourism represents a new record for the bacterial flora in Sharm El-Sheikh which introduces a reasonable key for comparing SSTIs in such area with another different geographical area with no occasional tourism activity in El-Sheikh Zaied which represent the wild type for SSTIs microflora.

\section{Materials and Methods}

One hundred consecutive bacterial isolates were collected from wound and soft tissue infections from two hospital (50 from each one) different geographical and social areas; a standardized 
questionnaire was administered to all consenting patients. This questionnaire used items for Distribution of samples; age, gender, nationality, and body site of infection.

\section{Collection and preparation of samples}

Total of randomly 100 samples (50 from each hospital) were taken from the intensive care units patient, in patients, and outpatients, for the bacteriological culture examination, the routine examination was carried out in the bacteriology sections, microbiology departments of two different hospitals. Patients who received systemic or tropical antibiotic treatment were excluded (Collee et al., 1996). Sample colure, shape, size and the presence or absence of granules was recorded. From the draining tubes, $5 \mathrm{ml}$ of pus were collected and transferred to a sterile leak-proof. From the external infected site, samples were taken using a sterile cotton swabs (Cheesbrough, 2006).

\section{Bacterial Culturing of collected samples}

Drainage and swab samples were directly discharged in sterile physiological saline solution. Samples were serially diluted to $10^{-4}$. One hundred $\mu 1$ of each diluted sample was cultured on blood agar to isolate the infective gram positive cocci, and MacConkey agar to isolate the infective gram negative bacilli. Using a sterile loop or swab of the specimen, apply the inoculum to a small area of the plate, flame sterilizes the loop. When cool, or using a second sterile loop, spread the inoculum. This will ensure single colony growth and incubated at $37^{\circ} \mathrm{C}$ for $48 \mathrm{~h}$ to allow the growth and development of the infection causing bacteria (Alaidarous et al., 2017).

\section{Identification of the isolated bacteria}

\section{Morphological and biochemical characterization:}

The identification of bacteria was based on morphological and biochemical characteristics, was carried out on the isolates. Morphological characteristics observed for each bacteria colony after $48 \mathrm{hrs}$. of growth included colony appearance; shape, elevation, edge, optical characteristics, consistency, colony surface and pigmentation. Culture plates of MacConkey agar, Blood agar, Eosin methylene blue agar, Nutrient agar and Mannitol salt agar (Hi Media, Oxoid) were used. Biochemical tests applied were standard catalase test, citrate utilization, coagulase, oxidase, methyl red, indole production, lactose fermentation test, urease test and Gram staining. Characterization and identification of the isolates was done using the methods of Olutiola et al., (1991); Fawole and Oso, (2004); Cheesbrough, (2006); Hemraj et al., (2013)

\section{Molecular identification}

\section{DNA extraction:}

A single bacterial colony from each selective agar plate was aseptically sent to the GIS Research Centre (6th October City, Egypt) for DNA extraction, rRNA PCR amplification and sequencing. DNA was extracted, amplified and purified using Quick-DNA Miniprep Plus Kits, ZYMO RESEARCH CORP., Irvine, California, United States, according to manufacturer protocol for solid tissues.

\section{PCR conditions and primers:}

Reactions were performed using (Delbes et al., 2007) method with slight modifications as follows: in a final volume of $50 \mu$ l. The reaction mixture contained $8 \mu 1$ template, $25 \mu$ l MyTaq Red Mix $(2 \mathrm{x})$, and $1 \mu \mathrm{l}$ of each primer (conc. $20 \mu \mathrm{mol} / \mathrm{l})$. The amplification program was denaturation; $1-5$ min, $95^{\circ} \mathrm{C}(1 \mathrm{cycle})$, then $30-36$ cycles of denaturation $\left(40-120 \mathrm{Sec}, 95^{\circ} \mathrm{C}\right)$, annealing temperature was $60{ }^{\circ} \mathrm{C}$ in case of bacteria; and extension $\left(5-7 \mathrm{~min}, 72{ }^{\circ} \mathrm{C}\right)$. Ten $\mu \mathrm{l}$ of PCR-amplified product was analyzed by electrophoresis on $0.9 \%$ ethidium bromide-stained agarose gel where the DNA ladder $(0.3$ $\mathrm{mg} / \mathrm{L})$ or bacterial suspension $(2 \mu \mathrm{l})$ was used as a template. Table (1) contains specific primers with expected amplicon sizes.

Table 1: Primers used for PCR, with the expected amplicon size

\begin{tabular}{llll}
\hline Isolate type & Primers & Amplicon size \\
\hline Bacteria & F & 5'-CAGGCCTAACACATGCAAGTC-3' & $1600 \mathrm{bp}$ \\
(16S rDNA) & $\mathrm{R}$ & 5'-CGGCGGWGTGTACAAGGC -3' & \\
\hline
\end{tabular}




\section{Results and Discussion}

During the study period 21 pathogenic samples of a total 50 patient were collected from Sharm El-Sheikh hospital 52\% females and 48\% males, as presented in Figure (1), while 34 pathogenic sample of a total 50 patient were collected from El-Sheikh Zaied hospital $62 \%$ females and 38\% males (Figure 2). Surgery and outpatient sample groups recorded the highest percentage pathogenic growth. In other study (Sowmya et al., 2014) observed males to be commonly infected than females.

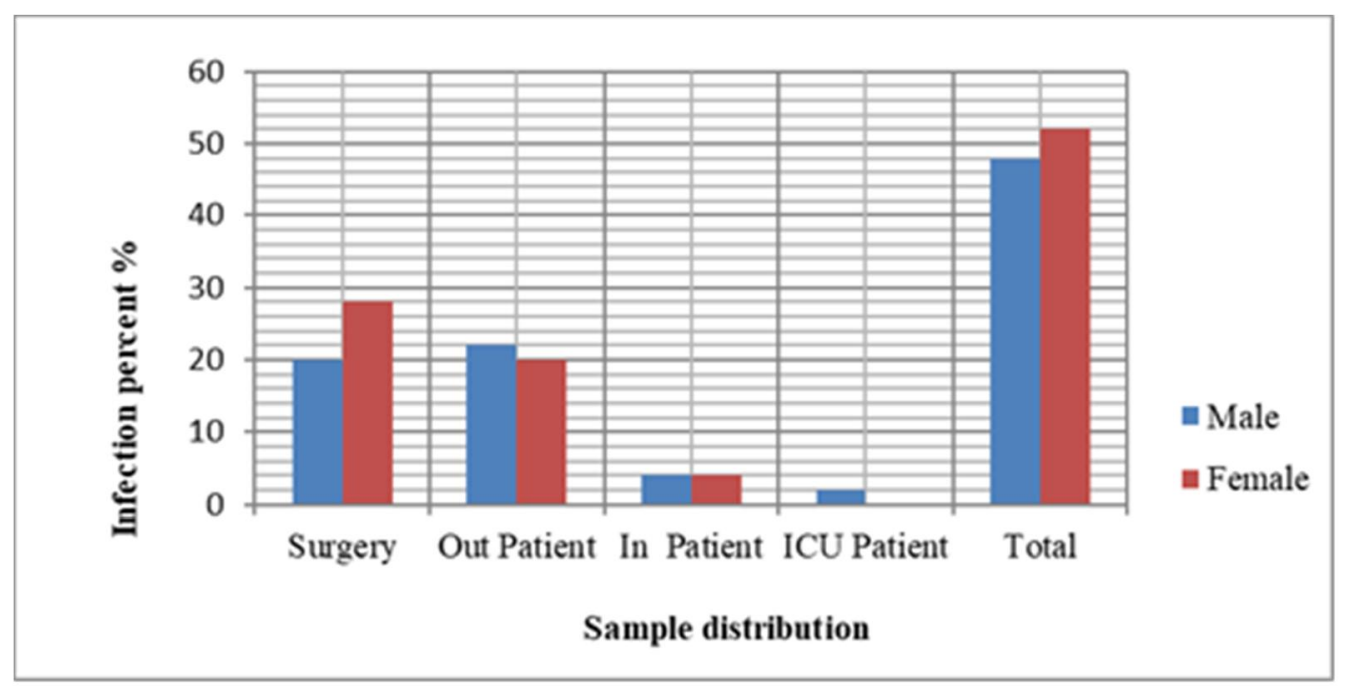

Fig. 1: Distribution and sources of samples (Sharm El sheikh city).

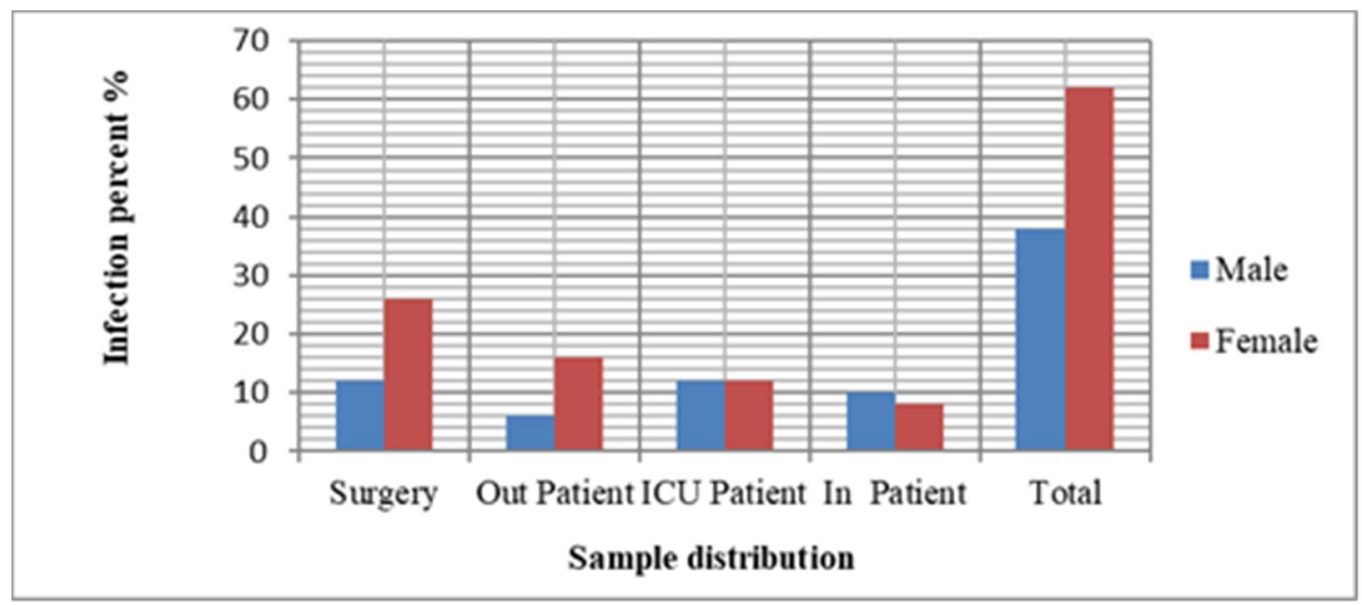

Fig. 2: Distribution and sources of samples (El sheikh zaied city)

It was found that in Sharm El-shiekh hospital that 4 types of bacterial species were isolated and identified by selective culture medium and standard biochemical tests. Among them, Staphylococcus aureus 7 of $21(33.3 \%)$ and Klebsiella pneumoniae 7 of $21(33.3 \%)$ was found to be the most common pathogen, the second common pathogen in our study was Pseudomonas areruginosa 4 of $21(19.0 \%)$ followed by E.coli 3 of 21 (14.3\%) Figure (3), while in El-shiekh Zaied hospital found that 7 type of bacterial species were isolated and identified. Among them, Klebsiella pneumoniae. 10 of 34 (29.4\%) was found to be the most common pathogen, the second common pathogen in our study was Pseudomonas areruginosa 9 of 34 (26.5\%) followed by Acinetobacter spp. 6 of 34 (17.6\%), E.coli 3 of $34(8.8 \%)$, Proteus mirabilis 3 of 34 (8.8\%), Staphylococcus aureus 2 of $34(6.0 \%)$ and morganella morganii 1 of 34 (3.0\%) Figure (4). In similar reports was observed by Ananth and Rajan, (2014) found that the Staphylococcus aureus (37.2\%) was the predominant isolate, second most was Pseudomonas aeruginosa (18.6\%) followed by Streptococcus pyogenes $(13.9 \%)$ and the lowest percentage was 
recorded by Proteus vulgaris (2.3\%). Sowmya et al., (2014) found that the staphylococcus aureus was the most common pathogenic, Rao et al., (2014) found that the E. coli the second common pathogen isolates percentage.

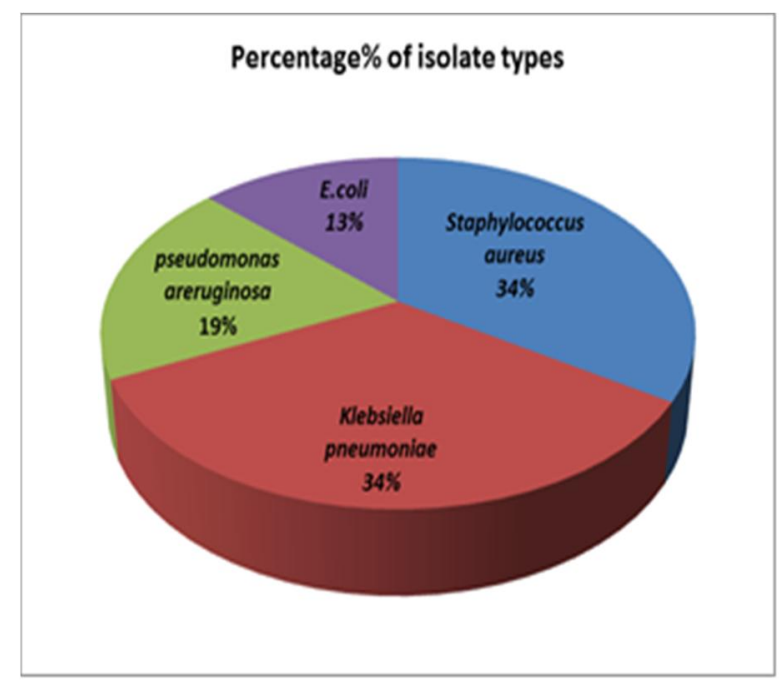

Fig. 3: The percentage (\%) of isolate types collected from Sharm El-Sheikh hospital

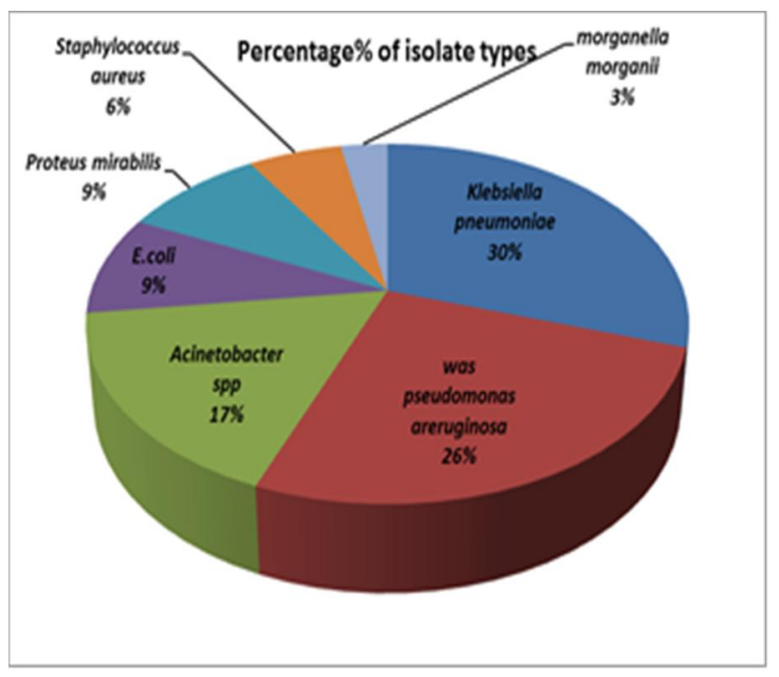

Fig. 4: The percentage (\%) of isolate types collected from El-Sheikh Zaied hospital

Upon colony morphology on selective and differential media, microscopic examination, catalase activity, coagulase, urease, methyl red, indole production, oxidase and the Gram staining the bacterial isolates have been divided in to 7 groups as shown in Table (2).

Identification by $16 \mathrm{~S}$ rRNA gene sequence analysis, the gel electrophoresis of samples loading after PCR run using 16S rRNA is shown in Figure (5)

The extracted DNA was purified and used for PCR amplification. As in Table (3), nucleotide sequencing of $16 \mathrm{~S}$ rRNA of the ten representative bacterial isolates from both area were determined to confirm biochemical identification. The obtained 16S rRNA sequences were compared with available $16 \mathrm{~S}$ rRNA sequences in the NCBI GenBank database using BLAST; one of the most heavily used sequence analysis tools available in the public domain.

There is now a wide choice of BLAST algorithms that can be used to search many different sequence databases and finds regions of similarity between theses biological sequences (McGinnis and Madden, 2004). Obtained sequence identifications were very reliable ( $\geq 96 \%$ similarity with the database). This alignment showed that the representative isolates in Sharm El-Sheikh were Escherichia coli strain TU-17 (accession number MF179683.1), Escherichia coli strain EGE 4874147-98 (accession number KY655122.1), Pseudomonas aeruginosa strain AUBPA34 (accession number KC253267.1), Staphylococcus aureus strain MSST25 (accession number KY485152.1) and in El-Sheikh Zaied were Staphylococcus aureus strain NBRC 102144 (accession number AB681718.1), Pseudomonas aeruginosa strain B3 (accession number MH938255.1), Klebsiella pneumoniae strain WH07 (accession number MG214488.1), Escherichia coli strain O157:H7 IRAQ8 (accession number MH782081.1), Proteus mirabilis strain 40X2 (accession number KX495210.1), Morganella morganii strain U2 (accession number MG489884.1). From these results observed that there are genetic differences in the same strain isolates from both areas.

The current research aimed to evaluate the effect of geographical and social difference on the distribution of skin and soft tissue infections. Surgery and outpatient sample groups recorded the highest percentage pathogenic growth; the SSTI was more common in female than male for both different cities.

There were clear variations in the distribution of pathogen - infected samples between Sharm El sheikh and El sheikh Zaied cities .The number of infected patient was more in El- Sheikh Zaied (68\%) than in Sharm El-Sheikh City (48\%), and the infected females were more than males in both cities. The isolates were biochemically grouped, and each group was further identified by $16 \mathrm{~S}$ rDNA gene fragments sequencing. 


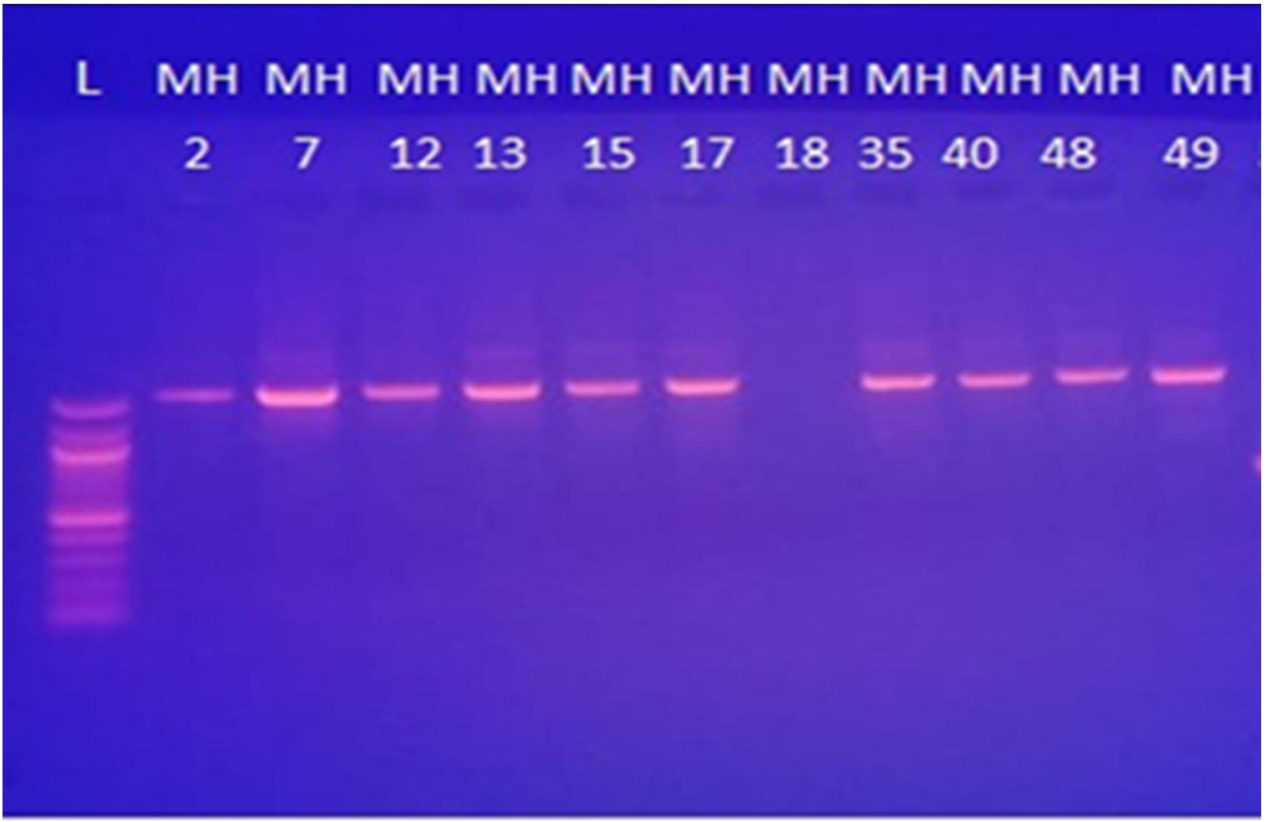

Fig. 5: Agarose gel electrophoresis of the PCR using the 16S rRNA primer

Table 3: Molecular identification of microbial isolates nucleotide sequences Conclusion

\begin{tabular}{|c|c|c|c|c|}
\hline Code & Isolate name & Isolation media & Accession number & Homology \% \\
\hline 2 & Morganella morganii strain U2 & MacConkey agar & MG489884.1 & $95 \%$ \\
\hline 7 & Proteus mirabilis strain $40 \mathrm{X} 2$ & MacConkey agar & KX495210.1 & $98 \%$ \\
\hline 12 & $\begin{array}{l}\text { Escherichia coli strain } \mathrm{O} 157: \mathrm{H} 7 \\
\text { IRAQ8 }\end{array}$ & Eosin methylene blue & MH782081.1 & $96 \%$ \\
\hline 13 & $\begin{array}{l}\text { Klebsiella pneumoniae strain } \\
\text { WH07 }\end{array}$ & Eosin methylene blue & MG214488.1 & $99 \%$ \\
\hline 15 & Pseudomonas aeruginosa strain B3 & MacConkey agar & MH938255.1 & $88 \%$ \\
\hline 18 & $\begin{array}{l}\text { Pseudomonas aeruginosa strain } \\
\text { AUBPA34 }\end{array}$ & MacConkey agar & KC253267.1 & $\% 95$ \\
\hline 35 & $\begin{array}{l}\text { Escherichia coli strain EGE } \\
4874147-98\end{array}$ & Eosin methylene blue & KY655122.1 & $97 \%$ \\
\hline 40 & $\begin{array}{l}\text { Staphylococcus aureus strain } \\
\text { NBRC } 102144\end{array}$ & Blood agar & AB681718.1 & $95 \%$ \\
\hline 48 & $\begin{array}{l}\text { Staphylococcus aureus strain } \\
\text { MSST25 }\end{array}$ & Blood agar & KY485152.1 & $92 \%$ \\
\hline 49 & Escherichia coli strain TU-17 & Eosin methylene blue & MF179683.1 & $98 \%$ \\
\hline
\end{tabular}

Alignment with NCIB database sequences revealed that they highest matched with Staphylococcus aureus, Klebsiella spp., Pseudomonas spp., E. coli, Acinetobacter spp., Proteus spp, and Morganella morganii. There were genetic differences between isolates belonging to the same genus in both areas, and this may be due to the climatic difference and the variation of activities in both different areas.

\section{References}

Alaidarous, M., M. Alanazi, and A. Abdel-Hadi, 2017. Isolation, identification, and antimicrobial susceptibility of bacteria associated with water pipe contaminants in selected area of Saudi Arabia. BioMed research international, 2017. https://doi.org/10.1155/2017/8042603.

Ananth, A. and S.Rajan, 2014. Isolation and screening of pathogenic bacteria from wound infections. Int J Curr Pharm Res, 6(3), pp.15-17.

Hemraj, V., Diksha, S. and Avneet, G., 2013. A review on commonly used biochemical test for bacteria. Innovare J Life Sci., 1(1):1-7.

Cheesbrough, M., 2006. District laboratory practice in tropical countries. Cambridge university press. 
Church, D., S. Elsayed, O. Reid, B. Winston and R. Lindsay, 2006. Burn wound infections. Clin Microbiol Rev., 19(2):403-34

Collee, J.G., A.G. Fraser, B.P. Marmion, and A.M. Simmons, 1996. McCartney Practical Medical Microbiology. Churchill Livingstone: $14^{\text {th }}$ ed: New York.

Delbès, C., L. Ali-Mandjee, and M.C. Montel, 2007. Monitoring bacterial communities in raw milk and cheese by culture-dependent and-independent 16S rRNA gene-based analyses. Appl. Environ. Microbiol., 73(6):1882-1891.

Fawole, M.O. and B.A. Oso, 2004. Characterization of bacteria: Laboratory manual of microbiology. Spectrum Book Ltd., Ibadan, Nigeria, pp.24-33.

Heinzelmann, M., M. Scott, and T. Lam, 2002. Factors predisposing to bacterial invasion and infection. The American Journal of Surgery, 183(2):179-190.

McCaig L.F., L.C. McDonald, S. Mandal, D.B. Jernigan, 2012. Staphylococcus aureus-associated skin and soft tissue infections in ambulatory care. Emerg Infect Dis; 18: 1715-23

McGinnis, S. and T.L. Madden, 2004. BLAST: at the core of a powerful and diverse set of sequence analysis tools. Nucleic acids research, 32(suppl_2), pp.W20-W25.

Olutiola, P.O., O. Famurewa, and H.G. Sonntag, 1991. An introduction to general microbiology: A practical approach. Heidelberger Verlagsanstalt und Druckerei GmbH Heidelberg, Germany

Rao, D.R., R. Basu, and D.R. Biswas, 2014. Aerobic Bacterial Profile and Antimicrobial Susceptibility Pattern of Pus Isolates in a South Indian Tertiary Care Hospital. Surgery, 36, pp.35-29.

Sowmya, N., S. Savitha, S. Mallure, K. Mohanakrishnan, G. Sumathi, and P. Arumugam, 2014. A two year study of spectrum of bacterial isolates from wound infections by aerobic culture and their antibiotic pattern in a tertiary care center. Int. J. Curr. Microbiol. App. Sci., 3(8), pp.292-295. 